EPiC Series in Language and Linguistics
Volume 2, 2017, Pages 304-314
Professional and Academic Discourse:
an Interdisciplinary Perspective

\title{
The Expression of Uncertainty as a Strategy for Mitigating the Assertion. An Analysis in an Oral Computerized Corpus
}

\author{
María José Barrios Sabador \\ Nebrija University, Madrid, Spain \\ mjbarrio@nebrija.es
}

\begin{abstract}
This paper looks into the use of probability markers in oral texts as a strategy used to weaken the illocutionary force involved in the assertive act. To meet this objective, twenty-three probability markers in five thousand paragraphs were analyzed. The analysis allowed us to see the use of thirteen of these markers to mitigate assertions in informal spoken language, mainly in peer-to-peer interactions with interpersonal purposes. In such contexts, probability markers usually protect the positive face of the speaker and occasionally that of the addressee. Some patterns are perceived concerning the scalar position of the marker (expression of more or less certainty) and whose face (speaker's or addressee's) is threatened by the potentially negative effect of the assertive act.
\end{abstract}

\section{Introduction}

This paper examines the use of probability markers in a set of oral interactions among Spanish speakers, all of them belonging to an informal register. The bulk of the occurrences with epistemic markers are dialogues between friends and, to a lesser extent, informal talks or interviews, representing day-to-day Spanish. As it has been pointed out in studies on mitigation and politeness, probability markers may encode the speaker's real uncertainty about a given state of affairs - modal meaning - or can be strategically used to reduce the illocutionary force of the speech act in order to modify the potentially unwelcome effects to the hearer or to the speaker. The first meaning is essentially semantic, and can be seen as a subjective device, since they shape the speaker's attitude toward the likelihood of the propositional content. As for the second one, it is pragmatic and has an intersubjective function that arises from their use "to reduce the force of utterances and thus protect both speaker's and addressee's face where the topic is sensitive” (Coates, 1987: 127).

Linguistically, mitigation (or attenuation) is linked to argumentative ends which seek to decrease the strength of assertion and therefore minimize disagreement and confrontation. Socially, mitigation 
is associated to face-preserving efforts, which can eventually involve politeness purposes (Briz, 2002: 21). This paper addresses three concepts central to the use of epistemic markers, such as mitigation, face and politeness. These concepts involve discursive functions that call for special examination concerning their subjective and intersubjective dimension. That is, mitigation, face and politeness are closely connected with the interactional attributes of modal markers in the communicative exchange.

\section{Preliminary remarks on face, mitigation and politeness}

The concept of face and its relevance to the study of mitigation and politeness have undergone much scientific study, not without controversy (Fraser, 1975, 1980; Leech, 1983, 2007, 2014; Holmes, 1984; Haverkate, 1986, 1994, 1996; Brown \& Levinson, 1987; Coates, 1987; Meyer-Hermann, 1988; Escandell Vidal, 1995; Caffi, 1999; Bravo, 2002; Briz, 2002, 2004, 2007; Santamaría García, 2003; Albelda, 2004, 2010; Kerbrat-Orecchioni, 2004; González Ruiz, 2005, 2007; Hidalgo Navarro, 2006; Taavitsainen \& Jucker, 2008; Albelda, 2010; Devís Herraiz, 2012; Briz \& Albelda, 2013; Hernández Flores, 2013, to name but a few). For the purpose of this study, and for reasons of space, I will limit myself to providing a brief overview - and therefore incomplete - on this matter.

As noted above, epistemic markers serve - besides their primary modal meaning - the pragmatic purposes of expressing the speaker's point of view in a way which seeks to maintain the speakeraddressee relationship, taking into account mutual face preservation in the social network. Such characterization involves notions of attenuation and politeness, two categories that must be distinguished with respect to these goals, although it is certainly the case that they can work together in many contexts, as stated by Fraser (1980: 344). Mitigation in assertions and exhortations is justified by their status as non-polite acts, that is, acts whose illocutionary purpose is not in the hearer's interest (Haverkate, 1994: 116). However, decreasing the illocutionary force of what is said, repairing and hiding one's intention are central goals more specifically linked to argumentation and seek agreement. Only occasionally the speaker's aim includes face preservation and, more specifically, politeness (Briz, 2007: 12). Whereas mitigation "involves a reduction in the unwelcome effect of what is done" (Fraser, 1980: 343), politeness bears directly on addressee's face (Albelda, 2004).

The concept of face, a key term in Brown and Levinson's theory (1987), became popular in the work of Erving Goffman (1955, 1967), who defines face as "an image of self delineated in terms of approved social attributes - albeit an image that others may share, as when a person makes a good showing for his profession or religion by making a good showing for himself" (Goffman, 1955: 213; 1967/1972: 5). ${ }^{1}$ Another concept in Brown and Levinson's theory is that of rationality, which must be seen as a set of capacities specifically related to the ability of reasoning on the basis of some objectives (Brown \& Levinson, 1987: 59-65). Rationality could take two forms: the reasoning behind the speech act and the evaluation of cost-benefit (Haverkate, 1994: 35-36). Both attitudes are exemplified by Haverkate in exhortations and assertions, the two kind of speech acts found in our data, with a clear predominance of the second.

In this respect, modal markers play a very important role as they modulate the speakers' commitment to the propositional content, encoding "their point of view towards what is being talked about” (Coates, 1990: 59). Modals could be used as boosters as well as downtoners (using Holmes' (1982) terminology), depending on the speaker's intentions: either to strengthen or to weaken the force of his speech act. In both cases, direct reference to sincerity conditions (Searle, 1976: 4) "is one

\footnotetext{
${ }^{1}$ This term has Chinese origins and dates back to Hu's work (1944), being a direct translation of lien and mien-tzu (Yau-fai Ho, 1976: 867). A salient feature of this concept stems from the correlation between the social selves (as pointed by Hernández Flores 2013: 183 and previously by Arundale (2006: 200-202)), an aspect which had already been outlined by Yau-fai Ho when describing face as not an individual thing, since it acquires its full meaning when it is "considered in relation to that of others in the social network” (Yau-fai Ho, 1976: 882).
} 
linguistic means of modifying illocutionary force” (Holmes, 1984: 347). As we will see below, modal markers expressing a high degree of certainty are preferred when the speaker refers to the hearer's knowledge about the question at hand in the communicative exchange. ${ }^{2}$

\section{Mitigation and the expression of uncertainty}

The linguistic expression of probability, which can be defined as the manifestation of an oriented uncertainty, serves a common goal of showing the lack of full commitment to the described state of affairs and smoothing the interactional parameters involved in the communicative exchange. Reference was made above to the subjective and intersubjective dimensions of probability markers. Such dimensions are intrinsically linked to the assumption that language is "an expression - an incarnation, even - of perceiving, feeling, speaking subjects" (Finegan, 1995: 2), who "must take a perspective on anything they express" and, consequently, this perspective "will shape expression" (Finegan, 1995: 4). Probability markers shape the propositional content so as to present it as a 'declaration' which does not necessarily depict a real state of affairs. Such elements are fuzzy following the designation of Lakoff (1973) and Zadeh (1975) - and show vague boundaries due to their semantics and their dependence on other members that form a scale that ranges from total uncertainty to absolute certainty.

Of course, the fact of taking a particular stance will serve interpersonal and pragmatic purposes, where the hearer also plays an important role. On the other hand, when epistemic modality qualifies an assertive, the lack of full commitment on the part of the speaker will preserve his face to a greater or lesser extent. As for directive acts, the concern for the hearer's face will be present in exhortations epistemically modalized. Nonetheless, it should be pointed out that in the vast majority of cases, probability markers modalize statements.

Statements correspond, in Searle's (1976) taxonomy, to representatives, the kind of illocutionary acts whereby the speaker expresses his commitment "(in varying degrees) to something's being the case" (Searle, 1976: 10). Directives, for their part, "are attempts (of varying degrees, [...]) by the speaker to get the hearer to do something” (Searle, 1976: 11). As highlighted by Searle, "belief collects not only statements, assertions, remarks and explanations, but also postulations, declarations, deductions and arguments" (Searle, 1976:4). Therefore, the expression of probability is related to assertion inasmuch as "hypothesizing that $p$ and flatly stating that $p$ are in the same line of business in a way that neither is like requesting" (Searle, 1976: 10). In the texts analyzed here, mitigation comes into play in two cases: (1) when the speech act may have unwelcome effects in the hearer and consequently, it also threatens the speaker's positive face, as in (1); (2) when the speech act reflects speaker's beliefs or attitudes in a way that may compromise his positive face as well, as (2) shows. In these contexts of self-criticism, the speaker goes one step ahead of possible criticism and holds himself up as an example. Both motivations are classified under the label of self-serving mitigation by Fraser (1980: 344-345).

(1) Paragraph 117. Seguramente (fragment) ${ }^{3}$

Cuando no viene un profesor, los niños están por la calle porque ni siquiera se dignan a poner sustitutos. O sea que Usted tendrá sequramente usted tendrá más información que yo, señora, pero vamos, le aseguro que la idea que tenía que si algún colegio público se cerraba era por falta lamentablemente, por falta de niños...

\footnotetext{
${ }^{2}$ Indeed, boosters would further improve the addressee's face, but they would not be appropriate in the cases reviewed here, considering that the speaker is not confident that the addressee has enough knowledge about what is talked about.

${ }^{3}$ All the texts analyzed here are spoken. At all time I have faithfully respected the original transcription. The word underlined shows the probability marker studied in the paragraph. For reasons of space, the content of each paragraph has been reduced in this paper.
} 
[When a teacher does not come to work, kids are wandering away because they don't even lower themselves to hire substitutes. I mean You may have certainly you may have more information than I do, ma'am, but come on, I can assure you that your idea of public schools closing due to the lack unfortunately, due to the lack of children...]

(2) Paragraph 363. Quizás (fragment)

Aún no sé, yo creo que la literatura debe ir, de una vez, no sé, hacia un quizás, aunque sea un poco estúpido lo que digo, pero, hacia la desaparición de los géneros [...].Además, creo que la literatura, de alguna forma, va hacia eso, de alguna manera, no sé. Quizás quizás sea una idea un tanto peregrina, pero yo quizás lo vea así.

[I don't know yet, I think literature must go, once and for all, I don't know, toward a maybe, although it may be a bit silly what I'm saying, but, toward the disappearance of genres [...]. Besides, I think literature, somehow, goes toward that, somehow, I don't know. Maybe maybe it's a bit senseless idea, but maybe I see it this way.]

The expression of mitigation and the declaration of real uncertainty have in common their scalar nature and the fact that they comprise a set of heterogeneous linguistic devices. A great deal has been written about these issues and I do not intend to address all these questions, since it would be an unrealistic purpose. I will focus on Haverkate's classification of mitigation strategies, without ignoring other basic specifications proposed by different scholars. Haverkate (1994) distinguishes two levels of implementation in mitigation strategies: the macro-discourse level and the micro-speech act level. In the macro-discourse level, the three resources to minimize disagreement are the expression of uncertainty in a dissenting view, an impersonal approach to the grounds of disagreement and expressing dissent as partial agreement (Haverkate, 1994: 117). As for the micro-speech act level, a distinction can be made between the semantic and the pragmatic modification of the proposition. The first is related to the informative structure of the assertion and its most characteristic manifestation is the concessive sentence. The second concerns the extra-propositional level and has two basic categories: hedged performatives - a term coined by Fraser (1975) - and manipulations of truth value. Such manipulations can be lexical (strategic use of epistemic, dubitative and doxastic predicates, for example) or deictic (alterations of the deictic centre and use of cognitive verbs). In our data, all these phenomena coexist with probability markers both in mirroring the speaker's real uncertainty and when he is attempting to attenuate his statement. Another traditional classification is that of Caffi (1999), who extends Lakoff's (1973) metaphor and understands mitigation as a phenomenon that works in different scopes, which she gathers around three focuses: the proposition, the illocution and the deictic origin of the utterance, to which correspond, respectively, the types of mitigators referred to as bushes, hedges and shields (Caffi, 1999: 888). The first category corresponds to Briz's (1995, 1998) attenuation of what is said, whereas the second and the third equate with the attenuation of the saying (Briz, 1995, 1998; Albelda, 2010: 51).

\section{A Quantitative and Qualitative View of Modal Markers as Mitigating Devices}

My study is corpus-based. The data come from the Corpus de Referencia del Español Actual (henceforth CREA), where I have chosen only spoken texts (5000 paragraphs), in order to check the use of twenty-three probability components by Spanish native speakers. All the instances selected (548 paragraphs) involve two-party conversations in symmetric contexts. The bulk of these texts include statements. Only a very small portion of them are exhortations. In most cases, these instances show interactions between friends, members of a family and less frequently, informal interviews. The average length of the paragraphs is 13-15 lines (217-256 words approximately). 


\begin{tabular}{|c|c|c|}
\hline & $\begin{array}{l}\text { NUMBER OF } \\
\text { PARAGRAPHS }\end{array}$ & $\begin{array}{l}\text { NUMBER OF } \\
\text { PARAGRAPHS WITH } \\
\text { MITIGATION } \\
\text { STRATEGIES } \\
\end{array}$ \\
\hline QUIZÁ(S) [perhaps, maybe] & 1283 & 198 \\
\hline TAL VEZ [perhaps, maybe] & 228 & 34 \\
\hline IGUAL [perhaps, maybe] & 178 & 24 \\
\hline A LO MEJOR [perhaps, maybe] & 1381 & 170 \\
\hline ES POSIBLE QUE [it is possible that] & 103 & 10 \\
\hline SEGURAMENTE [probably, very likely] & 285 & 26 \\
\hline PUEDE (SER) QUE [it might be] & 102 & 9 \\
\hline PROBABLEMENTE [probably] & 330 & 29 \\
\hline POSIBLEMENTE [possibly] & 188 & 16 \\
\hline SEGURO QUE [it is certain] & 196 & 13 \\
\hline ESTAR SEGURO DE QUE [to be sure that] & 71 & 4 \\
\hline $\begin{array}{l}\text { CONDICIONAL DE PROBABILIDAD DE SER [may have } \\
\text { been] }\end{array}$ & 463 & 3 \\
\hline FUTURO DE PROBABILIDAD DE SER [may be] & $\begin{array}{l}103 \\
\text { TOTAL: } \\
4911\end{array}$ & $548(11.16 \%)$ \\
\hline
\end{tabular}

Table 1: Probability markers with occurrences of mitigation

Table 1 shows that quizá(s), tal vez, igual and a lo mejor are recurrent when attempting at softening the assertion, followed some way behind by es posible que, all of them indicative of a high level of uncertainty. ${ }^{4}$ The lowest number of cases occurs in the future and conditional of conjecture. As Figure 1 shows, it is nonetheless true that seguramente occupies an intermediate position, ahead of puede ser que, probablemente and posiblemente, all of them showing a lower level of certainty. We cannot ignore either the last position of the future and conditional of conjecture, both indexing a midlevel of uncertainty. ${ }^{5}$

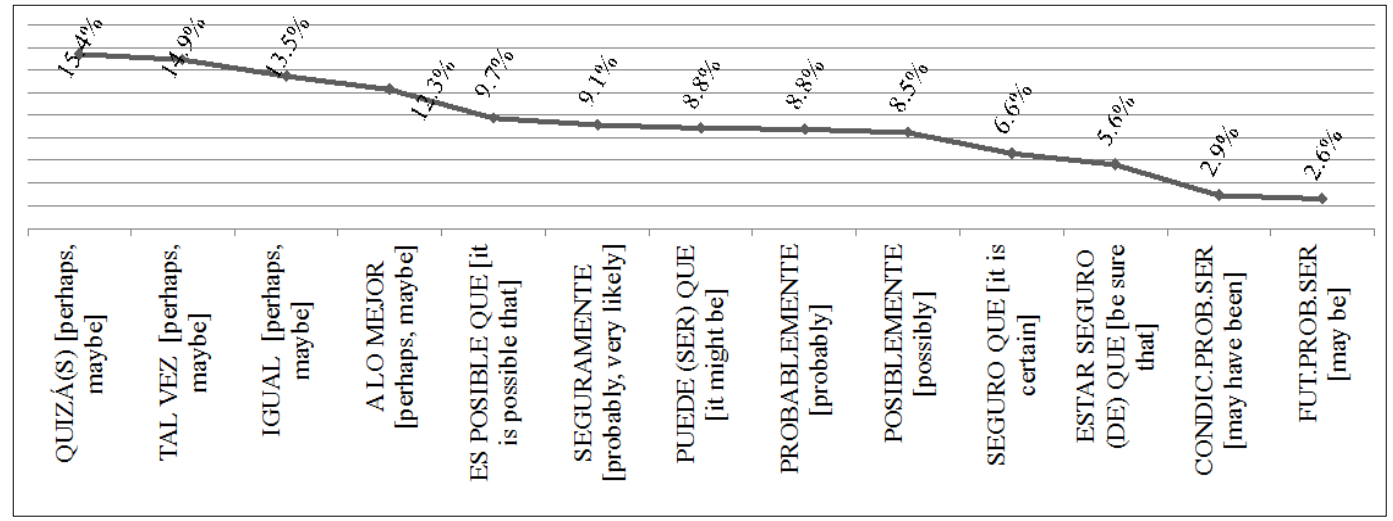

Figure 1: Modal markers mitigating the assertion

${ }^{4}$ We should keep in mind that there are 103 occurrences of es posible que, a number significantly lower than those of quizá[s] (1283), tal vez (228) or seguramente (285), a fact which indicates a decrease in statistical significance. Markers without instances of mitigation have not been included in the table.

${ }^{5}$ The future and conditional tenses in Spanish have a fuzzy scalar level which is highly context-sensitive, largely determined by the presence of elements such as dubitative expressions, reformulations or items referring to speaker's reliability, such as the presentation of arguments supporting the grounds for his modalized assertion (Barrios Sabador, 2012). 
The main difficulty in determining whether attenuation or real uncertainty is at work lies, as Albelda (2010: 50) points out, in the fact that some linguistic forms may or may not play an attenuation role. That is the case for probability markers and cognitive verbs in assertives $(13.5 \%$ in the paragraphs analyzed), since they may act as operators of mitigation in opinions but also as indicators of the speaker's lack of commitment to the propositional content. Some formal clues which help to identify mitigation are reformulations and corrections by the speaker himself, as well as the use of concessive sentences. Our research found some ambiguous contexts when creer 'think' or parecer 'seem' were involved, whereas lexemes such as imaginar 'imagine' and suponer 'suppose', due to their semantic properties, lead to an unambiguous modal reading (Barrios Sabador, 2012).

In our research data, the main reason for using probability markers has to do with the speaker's need for protecting his positive face, whereas preserving the hearer's face is not usually a pressing need. It is important to stress that we are faced here with assertives (from categorical to hesitating ones), therefore it should be no surprise that the face at risk is that of the speaker, unless the coparticipant in the speech event is involved in his statement. However, mitigation is also perceived in contexts where neither the speaker's face nor the hearer's face seem to be threatened:

\section{(3) Paraghaph 59. Puede que (fragment)}

con la cantidad de aves que hay en este museo, puede que yo marque siempre, vea siempre con admiración, un cernícalo que está posado con tan natural es sencillamente, es un animalito que ha venido volando...

[despite the large number of birds in this museum, I may always mark, I may always regard with awe, a kestrel perched on a branch as natural it's simply, it is a tiny creature which came flying...]

The context of probability markers with a mitigating motivation in the CREA attests the frequent accumulation of other mitigating devices so as to weaken further the illocutive force of the utterance: other probability markers, cognitive verbs (creer 'think', imaginar 'imagine', parecer 'seem', among the most frequent), ${ }^{6}$ marks signaling hesitation (no sé 'I don't know', vaya usted a saber 'your guess is as good as mine'), or an explicit statement of lack of accurate information (pongo en cuarentena lo que voy a decir 'I put what I'm going to say into quarantine', no podemos afirmarlo con certeza 'we cannot state that with certainty', to name a few examples). Other mechanisms which can be clustered around deictic procedures are impersonal constructions (such as the impersonal pronouns uno 'one' or se) as well as generalizations and vague words, typical in informal spoken language. All these devices "have a modal value, weaken the illocutive force of what is said or done, put on hold what is evidential” (Briz, 2002: 25).

Our research detected the presence of probability markers - both in the expression of uncertainty and mitigation - in a series of environments belonging to the semantic area of the causality, such as causal, concessive, adversative, illative and conditional constructions. The presence of causal constructions is consistent with the quality of rationality, being the justification of the speech act (read: causality constructions) one of its main manifestations, as Haverkate points out (1994: 35-36). A combination of some of these different phenomena is seen in the two paragraphs below:

\section{(4) Paragraph 60. Tal vez (fragment)}

$Y$ el público cuando se mete con usted le llama indio. ¿Somos un pueblo racista los españoles? $\underline{\text { Tal }}$ vez tal vez puede que haya algo de influencia, pero yo creo que más o menos en todos los países se comentan adjetivos, como cuando se quiere molestar o insultar a alguien, ¿no? Hugo Como a los gringos Sí. y todo eso, ¿no?

[And the public when the public picks on you, they call you Indian. Are we racist people, the Spanish? Maybe, maybe it is possible that there is some influence, but I think that more or less in

\footnotetext{
${ }^{6}$ For an explanation of differences between probability markers and cognitive predicates, see Langacker (1990, 1991/2002) and Barrios Sabador (2012).
} 
all countries adjectives are commented, as when somebody wants to be a nuisance or to insult someone, right? Hugo As the gringos Yeah. And all that, right?]

\section{(5) Paragraph 185. Seguro que (fragment) ${ }^{7}$}

Yo creo que no hay nadie que sea perfecto, lo que pasa es que en unos casos se sabe más y en otros casos se sabe menos. Pero, no hay nadie que sea perfecto y sequro que debo tener, y los tengo, muchos defectos, y que son conocidos, lo que pasa es que a veces generosamente pues la gente no los menciona.

[I think nobody is perfect, it is just that in some cases more is known whereas in others less is known. But nobody is perfect and it is certain that I must have, and I have, lots of defects, and they are known, it's just that sometimes, generously, people don't mention them.]

Our analysis witnesses an increased use of low epistemic certainty adverbs to mitigate the force of the propositional content stated (see Figure 1). The expression of a low degree of certainty illustrates the consubstantial link between the expression of uncertainty and its rethorical function of smoothing mutual frictions and letting the conversation flow easily. That happens in (6), with an anomalous use of quizá modalizing an appeal to the audience. Note also the presence of the 1st person plural in order to include the speaker in the exhortation and therefore minimize potential criticisms.

\section{(6) Paragraph 137. Quizás (fragment)}

¿Pero qué ocurre? Bueno, pues, quizás, designorémonos un poco. En un escrito que se llama El Evangelio de Juan hubo un señor llamado Pilato, que tuvo que oír una acusación contra un tal Jesús de Nazaret. ${ }^{8}$

[But what happens? Well, maybe, let's know a bit. In a written statement called John's Gospel, there was a man called Pilate, who had to listen to an accusation against a certain Jesus of Nazareth.]

Adverbs meaning a high degree of certainty, such as seguro que 'it is certain' and seguramente 'probably'/ 'very likely' are preferred in radio and TV shows when it is the addressee's face which may be threatened. In (7), the speaker expresses his disagreement; in (8), the speaker attributes knowledge or certain skills to the addressee:

(7) Paragraph 30. Seguramente (fragment)

Sequramente, a lo que se refería este señor, el presidente de la asociación inglesa, que no sé exactamente a qué situación se refería, pero puede haber visto una muerte especialmente pacífica..

[Probably what this gentleman was referring to, the president of the English association, I do not know exactly what situation was referring to, but he may have seen a particularly peaceful death.]

\section{(8) Paragraph 115. Seguro que (fragment)}

Yo soy Enrique, y canto. Yo soy Ramón. Toco la guitarra y canto en mi casa. A lo mejor con esta presentación ustedes no se han enterado de quién son ellos, pero en cuanto yo diga el nombre de su grupo sequro que les reconocen. Ellos son Los Secretos, nos presentan su último disco...

[My name is Enrique, and I sing. My name is Ramón. I play the guitar and I sing at home. You may have not got wind of who they are with this presentation, but as soon as I say the name of the group, it is certain you'll recognize them. They are Los Secretos, they are presenting their latest album...]

Clear-cut cases of attenuation are identified in contexts where the speaker is supposed to be certain about the topic of conversation, since he talks about past or present habits or comments on his

\footnotetext{
${ }^{7}$ Note here the self-criticism, in accordance with the D constraint (Modesty) of Leech (2007: 182, 184-186): "Place a low value on S's qualities". Notice also the reformulation of the probability sentence as an assertion.

${ }^{8}$ It should be noted that "designorar" does not exist in Spanish. Ignorar means 'be unaware', 'not know'. The prefix desmeans negation, opposition or deprivation. Therefore, this translation is only approximate.
} 
character traits, frequently - though not exclusively - in some remarks which make him feel a bit uneasy. Hence, expression of uncertainty prevents unwelcome criticisms or suspicions, as in (9):

(9) Paragraph 891. A lo mejor (fragment)

Mis padres, en ese sentido, son tradicionales, y tal vez lo que sí que eche en falta es un poco el diálogo, ¿no? No es que no exista, pero al haber un choque de generaciones entre mis padres y la mía, y la educación, un choque de educación, entonces, pues no existe, a lo mejor, el diálogo que yo querría. También en parte por mi culpa, ¿no?, o por culpa de ellos, no sé, es creo que es eso.

[In this respect, my parents are traditional, and perhaps what I do miss a bit is the dialogue, right? It is not that it doesn't exist, but since there is a clash of generations between that of my parents and mine, and education, a clash of education visions, then, maybe, there is no dialogue, the dialogue $\mathbf{I}$ would like to have. Partly my fault, right?, or their fault, I don' t know, it's I think it is that.]

A mitigating purpose is obvious in paragraphs where probability markers coexist with boosters, evaluative constructions or any kind of devices which express the speaker's confidence in his statement:

(10) Paragraph 818. Será (fragment)

$Y$ eso lo pondrán en todos los sitios. *Le* pondrán mucho ???... Lo están poniendo en muchos sitios ya, , ¿¿¿¿̇así??? que... ... entonces será... indiscutiblemente, innecesaria la la señal, porque si no...

[And they may put that everywhere. They may put a lot $\dot{\varepsilon}$ ??... They are already putting that in many places...this way??? So...then...the signal may be undoubtedly unnecessary, because otherwise...]

Example (11) combines the two factors that were mentioned just now. On the one side, the speaker is talking about something experienced - not subject to doubt -; on the other side, the presence of evaluative expressions shows that what we have here is the expression of opinions.

\section{(11) Paragraph 690. A lo mejor (fragment)}

A mí lo que me da mogollón de palo, es que mi madre, pues, yo que sé, es un poco inocente y tal, ¿no? Sí, pero estás tú aquí. No, en no, pero en el sentido que a lo mejor voy a salir y me dice: lleva cuidado y tal y si vas con alguna chica, ya sabes, que lleva cuidado.

[Me, what I'm ashamed loads of, it's my mother, well, I don't know, she is a little bit naive and that, right? Yes, but you're here. No, no, in the sense that, maybe, I'm going to go out and she tells me: take care and that and if yo go out with a girl, you know, take care.]

\section{Conclusions}

In this paper I have sought to make a modest and practical contribution to the study of the linkages between the expression of uncertainty and mitigation in the speech act of assertion. In order to achieve this goal, 5000 oral texts with probability markers were examined, and $11.6 \%$ proved to fulfill an essential purpose of attenuation. The bulk of the texts are examples of assertions in everyday communication situations involving, mainly, two people. Assertions may be potentially a facethreatening act (Brown and Levinson, 1978), both for the speaker and the addressee, depending on the topic under discussion and the situational factors, which play a significant role in choosing the most appropriate means for minimizing the potential for conflicts in the two-way process which constitutes the spontaneous conversation. The texts under examination correspond to cases that may be classified - according to the parameters laid out by Briz and Albelda (2013: 294) - as belonging to relationships between equals, in a framework of day-to-day interaction, planning on the go, with an interpersonal goal and an informal setting, hence falling within the scope of the colloquial axis, characterized as less likely to feature attenuation phenomena. Nevertheless, mitigation would be justified by the speaker's 
argumentative purpose, without this necessarily implying the presence of a controversial topic. As has been rightly noted, the expression of probability is a linguistic tool, a semantic and pragmatic resource which enables speakers to stand back and soothe down - and sometimes prevent - unintended consequences of their utterances.

My analysis of the data shows a highest number of cases of mitigation with low certainty markers, something in line with the aforementioned attenuative purpose. These probability markers preserve mainly the speaker's face, even in assertions where confrontation or disagreement cannot be clearly spotted. This pattern is in stark contrast with the resort to high-scalar exponents (seguro que and seguramente) where the addressee is presumed to have some knowledge or particular skills. The use of these adverbs is in interests of the hearer's positive face. Probability markers are assisted in this task by other linguistic devices, here at the service of the same attenuative aim: impersonal forms, generalizations - which convey subjective meanings (Scheibman, 2007: 112), such as the presence of the 2nd pronoun tú 'you', which should be seen as a generic indicator rather than an impersonal reference (Hidalgo Navarro, 1996: 172) and displacements of the deictic center, as pointed out by Haverkate (1994), or Briz and Albelda (2013), among many scholars. Whereas these devices blur the speaker's responsibility about the state of affairs he is depicting, the presence of causal, conditional, concessive and adversative sentences acknowledge him as a truthful and accurate interlocutor, as he respects the quality and quantity maxims established by Grice (1975), mainly two submaxims: "Make your contribution as informative as is required (for the current purposes of the exchange)" and "Do not say that for which you lack adequate evidence" (Grice, 1975: 45-46). At the same time, the use of expressions of doubt and hesitation or claiming lack of knowledge (in contradiction to Gricean rules) illustrate the importance of taking into account notions of semantics and pragmatics to address those 'antithetical' uses, which could be dismissed as inconsistent with descriptive grammar.

Finally the use of probability exponents as mitigating devices reveals an interactional function previously attested in corpus-based studies (Cornillie, 2010; Cabedo Nebot \& Cornillie, 2011; Cornillie \& Gras Manzano, 2015; De Cock, 2015), a question that I have not dealt with here but has been addressed in another paper (Barrios Sabador, forthcoming).

In sum, this approach to epistemic modality as a resource whereby speakers attempt to soften their utterances in such a way as to suit mainly argumentative purposes has sought to provide a better understanding of the procedural properties of probability markers and their prevalence in Spanish conversation.

\section{References}

Albelda, M. (2004). "Cortesía en diferentes situaciones comunicativas: la conversación coloquial y la entrevista sociológica semiformal”. In D. Bravo y A. Briz (eds.), Pragmática sociocultural: estudios sobre el discurso de cortesía en español, 109-134. Barcelona: Ariel.

Albelda, M. (2010). “¿Cómo se reconoce la atenuación? Una aproximación metodológica basada en el español peninsular hablado" [online]. In: F. Orletti y L. Mariottini (eds.), (Des)cortesía en español. Espacios teóricos y metodológicos para su estudio, 41-70. Roma: Università Roma Tre y Programa EDICE.

Arundale, R. (2006). "Face as relational and interactional: a communication framework for research on face, facework, and politeness”. Journal of Politeness Research, 2 (2), 193-216.

Barrios Sabador, M. J. (2012). La expresión de la probabilidad en el español nativo y no nativo. Una aproximación descriptiva, gramatical y pragmática. Tesis doctoral. Madrid: Nebrija University.

Barrios Sabador, M. J., forthcoming. "A lo mejor and igual. Epistemic and non epistemic meanings". 
Briz, A. (1995). "La atenuación en la conversación coloquial. Una categoría pragmática”. In L. Cortés (ed.), Actas del I Simposio sobre análisis del discurso oral, 103-122. Universidad de Almería: Servicio de Publicaciones.

Briz, A. (1998). El español coloquial. Esbozo de pragmagramática. Barcelona: Ariel.

Briz. A. (2002). "La estrategia atenuadora en la conversación cotidiana española”. In D. Bravo (ed.), Actas del Primer Coloquio del Programa EDICE, 17-46. Estocolmo: Programa EDICE.

Briz, A. (2004). "Aportaciones del análisis del discurso oral”. In J. Sánchez Lobato and I. Santos Gargallo, (eds.), Vademécum para la formación de profesores. Enseñar español como segunda lengua L2)/ lengua extranjera LE, 219-242. Madrid: SGEL.

Briz. A. (2007). "Para un análisis semántico, pragmático y sociopragmático de la cortesía atenuadora en España y América”. Lingüística Española Actual, 29 (1), 5-40.

Briz, A. and M. Albelda. (2013). "Una propuesta teórica y metodológica para el análisis de la atenuación lingüística en español y portugués. La base de un proyecto en común (ES.POR.ATENUACIÓN)”. Onomazein, 28, 288-319.

Brown, P. and S. C. Levinson. (1987). Politeness: some universals in language usage. Cambridge: Cambridge University Press.

Cabedo Nebot, A. and B. Cornillie. (2011). "On the prosody of subjective and intersubjective modal adverbs in Spanish". Paper presented in the $12^{\text {th }}$ International Pragmatics Association Conference (IPrA). Manchester, 3-8 July 2011.

Caffi, C. (1999). “On mitigation”. Journal of Pragmatics, 31, 881-909.

Coates, J. (1987). "Epistemic modality and spoken discourse". Transactions of the Philological Society, 85 (1), 110-131.

Cornillie, B. (2010). "An interactional approach to epistemic and evidential adverbs in Spanish conversation”. In G. Diewald and E. Smirnova (eds.), Linguistic Realization of Evidentiality in European Languages of Cognitive Linguistics, 309-330. Berlin: Mouton de Gruyter.

Cornillie, B. and P. Gras Manzano. (2015). "On the interactional dimension of evidentials: The case of the Spanish evidential discourse markers”. Discourse Studies, 17, 2, 141-161.

De Cock, B. (2015). "Subjectivity, intersubjectivity and non-subjectivity across spoken language genres". Spanish in Context, 12 (1), 10-34.

Devís Herraiz, E. (2012). "Cortesía atenuadora en el español coloquial”. Cauce. Revista internacional de Filología, Comunicación y sus Didácticas, 34-35, 117-138.

Finegan, E. (1995). "Subjectivity and subjectivisation: an introduction". In D. Stein and S. Wright (eds.), Subjectivity and subjectivisation. Linguistic perspectives, 1-13. Oxford: University Press.

Fraser, B. (1975). "Hedged performatives". In P. Cole and J. L. Morgan (eds.), Syntax and Semantics, 3, 187-211. Nueva York: Academic Press.

Fraser, B. (1980). “Conversational mitigation”. Journal of Pragmatics, 4, 341-350.

Goffman, E. 1955. "On Face-Work. An Analysis of Ritual Elements in Social Interaction". Psichiatry: Interpersonal and Biological Processes, 18 (3), 213-231.

Goffman, E. 1967/ 1972. Interaction Ritual. Essays on Face-to-Face Behaviour. London: Penguin University Books.

González Ruiz, R. (2005). "Esa será tu opinión. Aproximación al estudio de las funciones discursivas y sociales de los modalizadores de opinión en español actual”. Español Actual, 84, 75-98.

González Ruiz, R. (2007). "Personalmente, no lo considero viable. Acerca de la zona modal y de los valores estratégicos de una clase de adverbios de modalidad”. Lingüística Española Actual, 29 (1), 75-100.

Grice, H. P. (1975). "Logic and conversation”. In P. Cole y J. L. Morgan (eds.), Syntax and Semantics, 3: Speech Acts, 41-58. New York: Academic Press.

Haverkate, H. (1994). La cortesía verbal: estudio pragmalingüístico. Madrid: Gredos.

Hernández Flores, N. (2013). “Actividad de imagen: caracterización y tipología en la interacción comunicativa”. Pragmática Sociocultural, 1 (2), 175-198. 
Hidalgo Navarro, A. (1996). "Sobre los mecanismos de impersonalización en la conversación coloquial: el tú impersonal”. ELUA, 11, 163-176.

Hidalgo Navarro, A. (2006). "La expresión de cortesía en español hablado: marcas y recursos prosódicos para su reconocimiento en la conversación coloquial”. In M. Villayandre Llamazares (ed.), Actas del XXXV Simposio Internacional de la Sociedad Española de Lingüística, 957-979. Universidad de León.

Holmes, J. (1982). “Expressing doubt and certainty in English”. RELC Journal, 13 (2), 9-28.

Holmes, J. (1984). “Modifying illocutionary force”. Journal of Pragmatics, 8, 345-365.

Kerbrat-Orecchioni, C. (2004). “¿Es universal la cortesía?” In A. Briz y D. Bravo (eds.), Pragmática sociocultural: estudios sobre el discurso de cortesía en español, 39-53. Barcelona: Ariel Lingüística.

Lakoff, G. (1973). "Hedges: A Study in Meaning Criteria and the Logic of Fuzzy Concepts". Journal of Philosophical Logic, 2 (4), 458-508.

Langacker, R. W. (1990). “Subjectification”. Cognitive Linguistics, 1 (1), 5-38.

Langacker, R. W. (1991/ 2002). Concept, Image, and Symbol. The Cognitive Basis of Grammar. Berlin: Mouton de Gruyter.

Leech, G. N. (1983). Principles of Pragmatics. London: Longman.

Leech, G. N. (2007). "Politeness: Is there an East-West divide?” Journal of Politeness Research, 3, 167-206.

Leech, G. N. (2014). The pragmatics of politeness. New York: Oxford University Press.

Meyer-Hermann, R. (1988). "Atenuación e intensificación (análisis pragmático de sus formas y funciones en español hablado)”. Anuario de Estudios Filológicos, 11, 275-290.

Real Academia Española. (2008). Corpus de Referencia del Español Actual (CREA). Retrieved from http://www.rae.es/recursos/banco-de-datos/crea

Santamaría García, C. (2003). La negociación del acuerdo en la conversación coloquial. Estudio contrastivo español-inglés. Tesis doctoral. Madríd: Universidad Complutense.

Scheibman, J. (2007). "Subjective and intersubjective uses of generalizations in English conversations”. In R. Englebretson (ed.), Stancetaking in discourse: subjectivity, evaluation, interaction, 111-137. Amsterdam: John Benjamins.

Searle, J. R. (1976). “A classification of illocutionary acts”, Language in Society, 5, 1-23.

Taavitsainen, I. and A. H. Jucker. (2008). "Me thinks you seem more beautiful than ever". In A. H. Jucker and I. Taavitsainen (eds.), Speech Acts in the History of English, 195-228. John Benjamins.

Yau-fai Ho, D. (1976). "On the Concept of Face”. The American Journal of Sociology, 81 (4), 867-884.

Zadeh, L. A. 1975. “Fuzzy Logic and Approximate Reasoning”. Synthese, 30 (3/4), 407-428. 